Greg Penfold and Leon de Kock

Greg Penfold is a graduate of Stellenbosch University, and managing editor of Leadership magazine. Email: faustroll74@gmail.com Leon de Kock is Emeritus Professor of English at Stellenbosch University, Stellenbosch, South Africa. Email:leondk@sun.ac.za

\section{To a dubious critical salvation: Etienne Leroux and the canons of South African English criticism}

\title{
To a dubious critical salvation: Etienne Leroux and the canons of South African English criticism
}

This article presents a case study in cross-cultural literary reception following the act of literary translation - in this instance, of author Etienne Leroux — from Afrikaans into English. It describes the literary reception of Leroux in general terms, in Afrikaans and Dutch in the first place and subsequently in English (South Africanist) criticism. Our focus falls on the translation and subsequent reception of Leroux's major novel, Sewe dae by die Silbersteins, first published in Afrikaans in 1962, and crowned with the Hertzog Prize in 1964. The novel's rendering into English by poet Charles Eglington (Seven Days at the Silbersteins) in 1964 provides the centrepoint of our study. We argue that this translation, along with the several forms of what André Lefevere calls "rewriting" (in literary-critical registers) that it engendered, created disjunctive moments of cross-lingual critical reception in which dubious conclusions hardened into routine paraphrase or accepted "wisdom" in English criticism. By "rewriting" in this case, following Lefevere, we mean inter-lingual re-descriptions of literary works within literary-critical histories or reviews that are often based on translations, and on readings of them in relative isolation from their fuller context in the original language (here, Afrikaans). Keywords: Afrikaans literature, cross-cultural reception, Etienne Leroux, literary patronage systems, rewriting, Seven Days at the Silbersteins. South African English criticism, translation.

\section{Introduction}

The late Afrikaans critic and biographer J. C. Kannemeyer classes Etienne Leroux (1922-89) and J. M. Coetzee together as two of South Africa's most prominent novelists (J. M. Coetzee 23). André P. Brink, himself a veteran of self-translation and of critical as well as creative work, considers Leroux's Magersfontein, O Magersfontein! as not only the pinnacle of this author's work but also a brilliant novel in its own right, one that would be esteemed as a milestone in any literature (5). Leroux's standing within the Afrikaans literary canon is assured, both as an influential member of the Sestigers, the loose affiliation of writers who collectively constituted Afrikaans literature's great leap into (post)modernity, and as a two-times recipient of the Hertzog Prize, arguably the highest honour bestowed upon Afrikaans writers. Further afield, Leroux was the first Afrikaans author to be published to international acclaim in English translation, his work having been championed by Graham Greene, Paul Theroux and Stephen Gray, among others. Yet at the time of writing, although his collected works remain 
available in Afrikaans, the English translations of his work are long out of print; discussion of Leroux within English (South African) literary-critical historiography is largely centred on the political controversy around Sewe dae by die Silbersteins and Magersfontein, O Magersfontein!; and their literary merit has rarely been dealt with seriously in English critical literature-certainly not within the last two decades. In the case of Sewe dae by die Silbersteins, critical reception in English, in its most visible instances, is cursory, patronizing, and somewhat off the mark, as this article will suggest.

Our purpose, then, is to assess Leroux's reputation within English literary discourse as produced by various acts of rewriting over the course of his literary career, including literary translation. We use Lefevere's work, Translation, Rewriting, and the Manipulation of Literary Fame (1992), to provide a conceptual framework from within which to account for Leroux's fortunes within English South African literary patronage systems. In particular, the literary manipulation of Leroux by prominent English critics are brought to light and critiqued.

\section{'Rewriting' Leroux}

In an essay on the crisis of subjectivity in the novels of Leroux, "'Die krisis van die subjek in die soektog na betekenis" "The Crisis of the Subject and the Search for Meaning"), critic and literary historian Charles Malan (1987) draws a parallel with the reception and publication history of Byron's Don Juan. ${ }^{1}$ Byron's publisher tried to avoid controversy by publishing the first part of Byron's work anonymously and, by withholding publication details, endowed the poem with a life of its own. Other publishers and the press appropriated, abridged and repurposed the text to present an image of Don Juan as part of the current of anti-clerical literature, the yellow press and the sensational weekly press. Equally, argues Malan, the reception of Leroux's novels in South Africa yielded "die vreemdste nuwe tekste" ("the strangest new texts") (56).

According to Malan, Leroux laid bare the ideology underpinning Afrikanerdom, revealing "die ideologie agter en in die Afrikaner se sosiopolitieke, religieuse en moreel-filosofiese diskoerse tot in sy wese" ("the ideology behind and inside the Afrikaner's sociopolitical, religious and moral-philosophical discourses right down to the bone"). In reaction, ecclesiastical, political and cultural power structures were deployed to expel Leroux's most dangerous novels, Sewe dae by die Silbersteins and Magersfontein, OMagersfontein!, from the system as foreign bodies. Consequently, Sewe dae and Magersfontein suffered a similar fate to that of Don Juan: they were rewritten, "voorgestel of 'herskryf' as volksvreemde, godslasterlike, pornografiese en soortgelyke 'aanstootlike' geskrifte" ("presented or 'rewritten' as alien to the nation, blasphemous, pornographic and similarly 'offensive' pieces of writing"). Leroux reportedly could scarcely recognize his own texts as they were rewritten, or repurposed, in the form of articles, reports, letters to the press, censorship findings, and so on (56-7). 
Malan further likens these rewritings and the responses thereto by Leroux's (chiefly academic) supporters to a "teologiese tenniswedstryd" ("theological tennis match"), a dialectical struggle in response to "die ernstige aanstoot op godsdienstige en sedelike gebied" ("the [putatively] serious offence to religious and moral principles"), and represents Leroux as an apologist of subjectivity, "die kerk se grootste vyand in ons tyd" ("the church's biggest enemy in our time"), one which threatened to undermine any logocentric authority over the experiencing subject (57).

In describing certain rewritings of Leroux in this way, Malan rewrites the rewriters by inserting Leroux into the poststructuralist discourse prevalent in the 1980s, and also rewrites Leroux - providing a fine application of Lefevere's theory of rewriting, which reads partly as follows:

All rewritings, whatever their intention, reflect a certain ideology and a poetics and as such manipulate literature to function in a given society in a given way. Rewriting is manipulation, undertaken in the service of power, and in its positive aspect can help in the evolution of a literature and a society. Rewritings can introduce new concepts, new genres, new devices and the history of translation is the history also of literary innovation, of the shaping power of one culture upon another. But rewriting can also repress innovation, distort and contain, and in an age of ever increasing manipulation of all kinds, the study of the manipulation processes of literature as exemplified by translation can help us towards a greater awareness of the world in which we live. (Lefevere vii)

Thus, for Lefevere, "the acceptance or rejection, canonization or non-canonization of literary works" results from a process "dominated not by vague, but by very concrete factors [...] such as power, ideology, institution and manipulation", among which "rewriting in all its forms occupies a dominant position" as "the motor force behind literary evolution" (2). For Lefevere, literary translation is thus a key form of "rewriting", and as such is complicit in particular trajectories of literary reception. Translators, who "do not write literature, but rewrite it", are "responsible for the general reception and survival of works of literature among [...] the great majority of readers in our global culture [...] to at least the same, if not to a greater extent than the writers themselves" (1).

Cultural logic is subject to "a double control factor" intended to align the literary system "with the other subsystems society consists of". The first control factor falls "squarely within the literary system" and is exercised by "professionals such as critics, reviewers, teachers, translators [...] possessing a monopoly of competence" who "occasionally repress certain works of literature [...] opposed to the dominant concept of what literature should (be allowed to) be" (the dominant poetics), "and of what society should (be allowed to) be" (the dominant ideology) (14).

The second control factor is "patronage", namely the power to "further or hinder the reading, writing and rewriting of literature", as exercised by "persons, groups of 
persons, a religious body, a political party, a social class, a royal court, publishers, and [...] the media". The systems that patrons engage with to regulate "the distribution of literature" include "academies, censorship bureaus, critical journals, and [...] the educational establishment" (15). In his The Economy of Prestige (2009), James F. English similarly delineates how a "credential society" (see Collins), within Daniel Bell's conception of a post-industrial information-age system of exchange (compare Bell), relies on the implicit patronage of literary prizes, and similar acts of symbolic valueranking, to help constellate an "economy of prestige". The fortunes of writers-and of their works-are critically dependent on their stakes, or their holdings, within this reputational economy, in which patronage and prestige are key forms of symbolic capital (compare Bourdieu 84; see also Even-Zohar 290 on the interaction of the literary and ideological semiotic systems within an overarching cultural polysystem).

As an Afrikaans writer, Leroux was always subject to the logic of Afrikaans culture, and in turn to the double control factor of the Afrikaans literary system and cultural patronage system. The Afrikaans literary-cultural patronage system was, in Leroux's time, strongly determined by the ideological imperatives of State, Church, and volk, with whom publishers were in most cases complicit; as such, it can be described as largely undifferentiated. Socially influential objections to his divergence from hegemonic Afrikaner Nationalist ideology and poetics marginalised Leroux for many years; publishers recognized his talent but rejected his work as contrary to public taste and morals. As one publisher told him, "[j]y het talent, skryf liewerster wat die mense wil hê. Dan kan jy vir jou 'n Chev-motor koop"; ("You have talent, so rather write what people want to read. Then you can buy yourself a Chevrolet"; Kannemeyer, Leroux: ' $n$ Lewe 216). When, having abandoned two unpublished novels, he did at last see Die eerste lewe van Colet (1955) into print, Leroux had to stand surety for sales of 1000 copies in a three-month period, at a cost of 260 pounds sterling (Kannemeyer, Leroux 219). From an economic standpoint, Leroux was effectively his own patron, subsidizing his literary pursuits through farming on Wagenmakersdrift near Koffiefontein, the Le Roux family farm. Eventually, the status and controversy that came with the award of 1964 Herzog Prize for Sewe dae spread Leroux's name throughout South Africa and beyond, until he became the first Afrikaans novelist to acquire an international reputation. This success was entirely dependent on his fiction appearing in translation.

\section{Rise and fall: Leroux's literary fortunes in English translation}

Kannemeyer relates that in 1964, Johannesburg bookshop proprietor Philip Stein, seeking to boost the reputation of the Central News Agency (CNA) and aware that the Sestigers were becoming household names, decided to publish some of their titles in English translation. As part of this project, the then prominent South African English 
poet, journalist, translator and critic Charles Eglington was commissioned to render Sewe dae and its sequel, Een vir Azazel, into English (Kannemeyer, Leroux 426). Leroux's work thus became subject to a different cultural logic controlled by a divergent cultural and literary patronage system. This discrepancy influenced the reception of Leorux's work such that it diverged strongly—and in a decidedly southern direction following an initial bout of enthusiasm-from the stellar reception accorded the author in Afrikaans.

Leroux fully appreciated the benefits of translation. When the CNA launched Eglington's translation, Seven Days at the Silbersteins, he commented:

To be self-sufficient and outside the main stream of writing can only be to the detriment of the particular language concerned. Although deeply conscious of and influenced by one's literary heritage, one should keep closely in touch with other writing the way they do in a closely integrated continent like Europe. The vision of a writer, if it is really true and universal, is too important to be limited only to those who have access to the original language. But, more than that, it is important to see his work in a larger perspective. (Kannemeyer, Leroux 428)

Gareth Cornwell, former English in Africa editor (and co-author of the The Columbia Guide to South African Literature in English Since 1945), underscores the point: "English is the only world language spoken extensively in South Africa-and also the only South African language spoken extensively outside of the country [...] it is only through translation into English that works in [...] isiXhosa, isiZulu, Sesotho, Setswana, and even Afrikaans become accessible to a general readership" (4).

Despite relatively favourable publicity, Seven Days did not sell well; the CNA decided not to proceed with Azazel. Since Eglington had already begun the task of translation, Leroux thought it best to market his translated works overseas. In 1966, Leroux's South African publisher Koos Human asked the New York literary agent Jeanette Zimmermann to find an American publisher for Seven Days; she sold the rights to Houghton Mifflin in Boston, and Leroux's international career was well and truly under way. Seven Days appeared in November 1967, attracting enthusiastic praise ("fabulously interesting"; "beautifully written—like a jewel with many facets"; "puzzling and intriguing [...] brilliant tour de force"; "on every page there are such felicities that reading becomes a treasure hunt"); Graham Greene described it as: "A work of art which bridges the gap between Le Grand Meaulnes and Last Year at Marienbad with a humour all its own" (Kannemeyer, Leroux 436). Azazel was subsequently translated as One for the Devil (1968, Houghton Mifflin, trans. Eglington), with Die derde oog still later appearing as The Third Eye (1969, Houghton Mifflin, trans. Amy Starke). Seven days, Devil and Third Eye were also published in the UK by W. H. Allen in 1968, 1969 and 1969 respectively. 18-44, the first title of Leroux's Isis trilogy, was published by Houghton Mifflin in 1972 (trans. Cassandra Perrey); in the same year 
came what is generally considered Leroux's supreme achievement as regards international exposure: the single-volume publication of the Welgevonden trilogy as To a Dubious Salvation, in Penguin Modern Classics_-"die enigste Afrikaanse skrywer wat so vereer is" ("the only Afrikaans novelist to be thus honoured") (Kannemeyer, Leroux 471).

Thus in 1973, Stephen Gray could confidently state of Etienne Leroux that "his controversial work has reached a wider audience than that of any other Afrikaans author" (197). From then on, however, things took a sharp turn for the worse; now the patronage system of literary commerce to which Leroux, in English, was subject, spat him out. As Kannemeyer relates, the Houghton Mifflin edition of 18-44 sold only 800 copies of an initial print run of 3500. Zimmermann's alleged greed and arrogance ruined any possibility of Seven Days being filmed by the likes of Peter Brook and Alan Resnais. More damagingly, Zimmermann is said to have neglected to pursue enquiries from Finnish, Swedish, French and Norwegian publishers. Then Houghton Mifflin decided not to publish any further instalments of the Isis trilogy. Editor Joyce Hartman had already found the imagery of 18-44 "repetitive and laboured"; ${ }^{2}$ Greene's keen endorsement of Isis in translation, which he read in manuscript, availed nothing. Meanwhile, Gray—along with graduate student Louis van Rooyen—in 1974 produced a translation of $\mathrm{Na}^{\prime} v a$, the final title of the Isis trilogy. Gray and Van Rooyen's translation, however, was not even considered for publication. Kannemeyer writes that both manuscripts were misplaced by a literary agent (Leroux 629), although Gray feels that in the case of $\mathrm{Na}^{\prime} \mathrm{v}$ a this is probably not true; according to Gray, the manuscript should still be lodged in Human \& Rousseau's archives. ${ }^{3}$

In defence against Hartman's charge, in connection with $\mathrm{Na}^{\prime} v a$, that "Leroux's references, in each succeeding work, grow more arcane and more impenetrable", Koos Human said that a South African who read the book in Afrikaans would probably grasp many references and innuendoes that might escape a foreign reader. He added that many of the references in $N a^{\prime} v a$ were to earlier works unavailable in English and consequently would make no sense to an American reader (Kannemeyer, Leroux 543).

Gray and Van Rooyen's translation of $N a^{\prime} v a$ is an especially acute loss, that is, if it cannot be uncovered in Human \& Rousseau's "archives" (matter still pending at the time of publication). In that novel Leroux, as Brink wrote, had set himself the tremendously difficult task of not only completing the Isis trilogy, but also writing " $\mathrm{n}$ oorkoepelende roman [...] wat'n sluitsteen sou vorm vir al drie sy trilogiëe tot dusver" ("an overarching novel [...] which would form a keystone for all three his trilogies so far"); as Elize Botha remarked: "Daarom dwing dit die leser terug na die agt boeke wat hieraan voorafgegaan het, dring dit aan op herontdekking, maar wys dit ook op die eindelose moontlike herformuleringe van stellinge wat in die reeks boeke ingeneem is" ("For this reason, it compels the reader to go back to the eight books that came before this one, insisting on rediscovery, and also indicating the endless 
possibilities for reformulating propositions contained in this series of books"; Kannemeyer, Leroux 517).

Unfortunately, Leroux's achievement in completing his nine-novel cycle remains virtually unknown outside the Afrikaans academy. Whereas literary historian and critic H. P. van Coller, for example, considers it a work unique in South African literature, exhibiting both great complexity and surprising unity, to be read as a polyinterpretable whole (13), English-speaking scholars (as well as editors) without sufficient proficiency, or interest, in Afrikaans—or through sheer wilfulness-have in certain key instances formed a truncated impression limited by an undifferentiated patronage system to four titles out of nine, translated, moreover, by three different translators. In practice, Seven Days is the only novel in the cycle that is discussed in any detail in English critical literature. (See, for example, chapters by Gerrit Olivier, Hein Willemse and Michael Green in The Cambridge History of South African Literature, with the other title that occasionally comes up being Magersfontein, as in Louise Viljoen's entry in the Cambridge History; these chapters, it should be noted, are circumscribed by period and thematic constraints.) Nonetheless, in most instances Seven Days, along with an occasional reference to Magersfontein, becomes the litmus test for Leroux's entire oeuvre, that is, in durable and prominent English criticism voiced by influential figures like writer-critic Jack Cope and top-rated scholar Michael Chapman, as we suggest below.

After the $N a^{\prime} v a$ translation failed to find traction, matters worsened. Even as his stock peaked in Afrikaans literary circles with the publication of Magersfontein, which earned him his second Herzog Prize (1979) as well as a ban under the Publications Act of 1974, Leroux's international reputation began to erode. According to Brink, Leroux had created in Magersfontein "dalk sy heel sinrykste Suid-Afrikaanse 'mite' tot dusver: deur naamlik die stuk Suid-Afrikaanse geskiedenis self te mitifiseer en dan paradigmas daarop te baseer" ("perhaps his most meaningful South African 'myth' until now: more particularly by mythologizing a piece of South African history itself and then building paradigms on the basis of it"; Kannemeyer, Leroux 579). However, publishers outside of South Africa rejected Magersfontein as being too foreign to British readers' tastes. South African publisher AD Donker expressed interest in publishing a translation by Marijke van der Walt, but although both Human and Leroux were very satisfied with the standard of the translation, the publisher, Donker, for reasons unknown, declined to publish (Kannemeyer, Leroux 629). Thereupon the manuscript was handed over to the British firm Hutchinson, which commissioned a new translation from one Ninon Roets, ultimately publishing Magersfontein in 1983 (Kannemeyer, Leroux 631).

This English translation of Magersfontein proved disastrous. Greene wrote to Leroux on 24 May 1983 that his "amusement and appreciation were damaged by your execrable publisher who must have broken the Guinness Record for misprints", adding that he 
found the translation "unsatisfactory", the translator seemingly unable to distinguish between "its" and "it's" and also using "some very ugly words I can't even find in the thirteen volumes of the Oxford English Dictionary", including oddities such as "logisticions" and "fetishistacely" (Kannemeyer, Leroux 628-31).

No further translations of Leroux's works appeared in his lifetime. The last to appear to date was the Dutch version of Magersfontein (1999), translated by Ingrid Glorie. By the 1980s, Leroux's international reputation had dwindled almost completely. Dutch critic Hans Ester remarks that he was no longer "de onomstreden literaire grootmeester, as welke hij [...] in 1970 [...] werd gepresenteerd" ("the controversial literary grand-master, such as he was presented as being in 1970"). Ester attributes this to the changing expectations of European readers:

In het beeld, dat Europeanen van de Zuidafrikaanse literatuur hebben, staat de Europese preoccupatie met raciale conflicten in Zuid-Afrika in het middelpunt. Een Zuidafrikaanse roman, die de Apartheid ignoreert, wordt naar de prullenbak verwezen of ten hoogste als historisch signifikiant document erkend. Sinds de jaren zeventig is de informatie over het wel en wee van Zuid-Afrika in de Europese media in zo sterk gedetailleerde vorm geboden, dat daarmee ook de verwachtingen van het Europese lezerspubliek ten aanzien van fictioneel proza uit Zuid-Afrika grondig zijn veranderd. $(103 \text {, italics added })^{4}$

The effect of this shift can be gauged by the reviews of the belated Norwegian translation of Seven day in the Norwegian press, as cited by Leroux:

Leroux gee geen goeie hoop op verbetering nie [...] Die enigste hoop is die broeiing van ontevredenheid onder die inboorlinge (Faedrelandsvennen—Sept 1980); (Leroux offers no hope for improvement [...] The only hope is the incubation of discontent among the indigenous peoples.)

Ek verkies die inboorlinge se eie mites uit dieselfde geografiese streke. Of Nadine Gordimer se wit oproer [...] Beeld die boek eintlik die ineenstorting van Suid-Afrika uit? Die verdwyning van die Europese beskawing? Ja seker. Maar so gewikkel in sulke ingewikkelde sluiers dat die kontak met die menslike wegbly. En dan is dit nie maklik om die leser se belangstelling te hou nie. (Bergens Tidende-Oct $1980)^{5}$

Kare Stoveland beskou Sewe Dae as "'n swerwing in rassistiese heerlikheid." (Leroux, "Vervreemding tussen leser en skrywer" 150); (Kare Stoveland regards Seven Days as a wandering about amid racist magnificence.)

Clearly the perceived lack of an unequivocal message of hope, overly sophisticated technique instead of a direct expression of South Africa's collapse and its sociopolitical malaise, to say nothing of the charge of "rassistiese heerlikheid" ("racist magnificence"), did little to advance Leroux's cause in Norway or Europe as a whole. 
By 2000, Leroux had been ousted from his position as top-ranking Afrikaans novelist. Although the Oxford Guide to Literature in English Translation does list Leroux among those Afrikaans writers who "in a relatively short time [...] joined the ranks of the world's best in all literary genres" and "have won international acclaim through translation" (France 136), it goes on to state that "of all the Afrikaans authors, André P. Brink is clearly the most renowned" - "the man who put Afrikaans literature on the international literary map" (France 136-7).

Brink certainly has had more texts translated than any other Afrikaans writer, appearing in dozens of languages. By contrast, Leroux has appeared only in Dutch, English, French and Norwegian and is out of print in all of them.

The Oxford Guide gives two reasons for Brink's success. The first is ideological:

Brink was one of the most influential Afrikaans writers to emerge during the cultural renewal of the 1960s, an Afrikaans movement not confined to Afrikaans literature but which influenced the whole social fabric of South Africa, challenging many social taboos and prejudices and assailing the literary, moral, religious and political conventions of the Afrikaner. Brink admits ${ }^{6}$ that he chose to write in Afrikaans because he believed that by means of his writing he could join the struggle to liberate blacks from oppression by whites, as well as fellow Afrikaners from the constricting ideology of apartheid. (France 137)

The second concerns translation. As the Oxford Guide states: "[A]lthough the banning in 1975 of his novel Kennis van die aand (Looking on Darkness, 1973) meant that his voice was silenced in his own country and in his own language, a disaster for any minority writer [...] it secured his career as a politically committed novelist and [self] translator" (137).

As Robert Berner puts it in his essay, "Etienne Leroux: a Jungian Introduction", "Brink has been able to proceed as a novelist because he has been his own translator. [...] Obviously the Afrikaans writer who must depend on foreign publishers to discover his work and finance its translation and publication is less fortunate" (134).

Today, Brink is often listed in literary reference works such as The Cambridge Guide to Literature in English and the Oxford Good Fiction Guide (2001), where he is crossreferenced with - and consequently deemed to have a similar standing to- J. M. Coetzee, Alan Paton and Nadine Gordimer.

Unlike Brink, Leroux lacked control over his literary image and was unable to rewrite himself to suit the expectations of his (European) readership.

The 'rewriting' of Leroux in the English Academy and the 'legend' of the 'Sestigers' If Leroux's brief spell in the limelight and subsequent obscurity is attributable in large part to the fortunes of his work in translation, the image of him that is preserved in the 
English-speaking academy is predominantly the work of prominent English-speaking writers and academics.

The English academic image of Leroux tends to conflate his achievement with what may be termed the "legend" of the "Sestigers". For instance, although Michael Green (792) recognises Leroux's historical importance for Afrikaans writing, saying that "Etienne Leroux's highly patterned, fantastical Sewe dae by die Silbersteins [...] could be considered seminal" for "a broader 'experimental line' in Afrikaans fiction", Green's focus shifts from the individual writer to the group rather than engaging with any particular work in anything more than general terms:

Leroux would, like the young Brink, associate himself with the Sestigers (literally Sixtiesers) [...] The majority of its most productive writers-who also included Breyten Breytenbach, Jan Rabie and Bartho Smit-brought their formative experiences as students and sojourners in France back to a South Africa in which they became increasingly politicized and opposed to the Nationalist establishment. (Green 790)

Brink describes a similarly politicized legend of Sestig. The "Sestigers", he writes, consciously introduced the then current vogues of experimentalism, existentialism and post-modernism into a literary scene still largely determined by nineteenthcentury techniques and by the severely localized expression of themes like drought, locusts and poor-whites. The enthusiasm with which this new wave of writing was received by younger Afrikaans readers soon added unexpected dimensions to the work of these so-called "Sestigers" ('Writers of the Sixties'): as a result of the conventions and taboos broken in their work, mainly in the fields of religion, morality, sex and narrative tradition, political implications were attached to what had started as a purely cultural, literary movement. The Afrikaner establishment, threatened by the new sophistication in indigenous writing, branded as traitors writers like Chris Barnard, Breyten Breytenbach, André Brink, Abraham de Vries, Etienne Leroux , Jan Rabie, Adam Small and Bartho Smit, and tried to ostracize them from their community: books were burned publicly, authors were denounced from the pulpit and in parliament, cultural organizations tried to boycott productions of plays, pressure was exerted on printers and publishers not to publish certain books. (Coetzee and Brink, A Land Apart 9-10)

Thus the "Sestigers" appear as a group of literary Young Turks who return from Paris and set about turning the house of Afrikaans literature upside-down with their fashionable but second-hand literary ideas. Prominent critic and literary historian Michael Chapman duly summarizes the situation for his English-speaking readers: "In Afrikaans literature, the parochial naturalism and realism of the plaasroman gave way, spectacularly, to an imitative Euro-modernism among a new generation of writers, 
many of whom had been influenced by sojourns in France" (248-9). This image coincides with the unflattering image of the "Sestigers" formed by a hostile Afrikaans critic as "uitbegroei in Frankryk met Sartre as vader en 'n straatvrou as moeder" ("incubated in France with Sartre as father and a streetwoman as mother"; Kannemeyer, Leroux 294).

As for Leroux, the received-but erroneous-idea persists that it was a meeting with Jan Rabie in Paris in 1954 that effectively galvanized his writing career. Leading South African novelist of the 1950s, 1960s and 1970s Jack Cope (The Adversary Within 109) says that Rabie "was able to distance himself from the hazy image of Afrikaner blood and soil, to preserve his identity and enter the struggle for creative individualism"; consequently, he "had a distinct influence on the younger fiction writers who were beginning to publish in the late 'fifties and early 'sixties". Cope, then constructs the image of Leroux as callow would-be writer:

His initial efforts at writing were unsuccessful and he could not find a publisher for his work. The next step was a prolonged trip abroad in the early 1950s during which he met Jan Rabie and Bartho Smit in Paris. The naïve young would-be writer from the Free State veld was impressed by the life-style and outlook of his fellow Afrikaners in 'Bohemia'. On his return he wrote and published three novels in quick succession. [...] Back from Paris he was caught up in the Sestiger moment 'and that was the beginning', as he says, condensing nearly a decade into a single sentence. (Cope, The Adversary Within 111)

This account, apparently based on a letter Cope had from Leroux, seems to be in good faith, but it jars with the facts. In the first instance, Rabie (b. 1920) was only two years older than Leroux (b. 1922; 34 years old when Die eerste lewe van Colet was published), while Smit (b. 1924) was two years younger than him. More significantly, though, the meeting with Jan Rabie came after the novel Colet was accepted for publication. It is therefore to the genesis of Colet that we must turn to discover the facts of the matter.

Kannemeyer relates that in 1950, Leroux met someone who was to influence most profoundly his development as a writer. Jan Greshoff was a Dutch expatriate writer with an established reputation in the Netherlands and Flanders. As editor of literary journals such as Den Gulden Winckel and Groot Nederland, Greshoff encouraged young writers and gave them the opportunity to publish their work. Characterised as "de spitste geest en de meest scherpe pen uit die tijd" "the most focused spirit and the sharpest critic of his era"), Greshoff was also a highly individual critic, satirist, polemicist and poet firmly opposed to "alle regimenterings van die gees" ("all regimentations of the human spirit") (Kannemeyer, Leroux 162-4). It was Greshoff who persuaded the conservative editorial board of Standpunte to take on Leroux's short story "Kaartjie vir Oortreding" ("Ticket for Trespassing"). Leroux promptly asked Greshoff to be his literary mentor: "Ek is bevrees dat ek in die verlede nog altyd 
in verset gekom het teen ander leermeesters omdat iets binne-in myself my oortuig het dat hulle my té veel na'n patroon wou vorm" ("I fear that in the past I have always come into conflict with mentors because something inside me convinces me that that they want to shape me too much in line with a particular pattern"; Kannemeyer, Leroux 165-6).

As Kannemeyer describes the matter, Greshoff duly mentored Leroux through numerous unpublished short stories and two unpublished novels. Leroux had therefore invested considerable time and energy on technical development by the time Colet appeared in 1955, as reflected in the appreciative comments of the few critics who reviewed it. In the Netherlands, prominent critic Pierre H. Dubois called it the first Afrikaans novel that was both "helemaal Afrikaans, [en] van intellectuele inzet en niveau helemaal 'europees'" ("completely Afrikaans, and completely European in terms of intellectual effort and level"); Greshoff praised Leroux's ability to free himself from the taboos and prejudices that had hindered the psychological novel hitherto; for Rob Antonissen, the "orakel van Grahamstad" ("oracle of Grahamstown"), Colet, demonstrating unprecedented pertinency in the handling of sexual contents as well as "iets meesterliks" ("something masterly") in the stream-of-consciousness ending, was the only novel of 1955 that gave reason for " $n$ sekere hoop" ("a certain hope") in the future of the form in Afrikaans (Kannemeyer, Leroux 167-70).

In many respects, then, in terms of technique and taboo, the iconoclasm attributed to the "Sestigers" had already been accomplished by Leroux during the 1950s, in his unpublished novels, in Colet, and in its sequels: Hilaria (1957), with its adoption of the "mythic method", and Die mugu (1959), described by Antonissen as "die eerste deugtig treffende beeld van' $n$ Westerse, ook Suid-Afrikaanse, maatskappy wat deur verlies van sy sin vir' $n$ 'lewende mite' tot mensdomsmassa ontmenslik is" ("the first properly hard-hitting image of a Western, but also South African, society that loses its senses to a 'living myth' and is dehumanized into mere human mass in the process"; Kannemeyer, Leroux 281). Unfortunately, these novels made little impact (untranslated, they scarcely registered with English critics at all). As Elize Botha points out, it took the polemics around Seven Days and the Hertzog Prize for Afrikaans critics to start paying serious attention to Leroux (587).

Cope's rewriting of Leroux's career served as a basis for Chapman to caricature the "Sestigers" — and Leroux in particular. Picking up on the legend of the "Sestigers", Chapman writes, in South African Literatures:

In the work of [...] the most prominent Sestigers, the existentialism of Camus and Beckett, in fictionalised labyrinthine forms, either loses itself in its own cleverness or jerks its concerns about good, evil, sex, anxiety and despair into mocking rebellions by renegade sons against the dour fathers of Afrikanerdom. Leroux's Sewe dae by die Silbersteins, translated into English as Seven Days at the Silbersteins (1962), for example, transforms the Afrikaans farm of blood and soil ${ }^{7}$ into a modern 
wine estate where nouveau riche materialism has run rampant in orgies of partying and in pseudo-or is it meant to be serious?-patter about sin, conversion and destiny. (249)

The description does not specify whether Seven days "loses itself in its own cleverness", "jerks about its concerns" or both, but as a novel of the "Afrikaans farm of blood and soil" it is clearly not being read in relation to Colet, Hilaria and Die mugu, all three of which were decidedly urban fictions.

Chapman then singles Leroux out for special attention:

Like the plays of Bartho Smit, Leroux's novels throw out provocative but largely unanalysable hints of religious-and even more elusively-political rebellion, not revolution. This is the stuff on which lecture-room interpretation thrives and students are expected, earnestly, to pick away at allusions and guesses, and to find ultimate sanction in comments by the authors such as: life is not political, it is absurd; my theme is theological terror, fear in its abstract manifestation. (249)

In this passage, statements made by Leroux on a particular occasion are paraphrased, out of context, and represented as his overall intent. In fact, the reference to "theological terror" and "abstract" fear stems from "Tegnieke, temas en toekomsplanne" ("Techniques, themes and future plans"), a speech Leroux gave at the Sestiger Symposium at the University of Cape Town in February 1973. Chapman's reduction evidently relies on Cope's translation of the same speech. A comparison of Cope's translation with Leroux's full, published statement, in turn, shows that Cope's rendering is somewhat misleading to begin with.

Cope's translation reads as follows; (note the absence of reference to "theological terror": Chapman conflates Cope's critical judgement_-"Seven Days could also be regarded in the category of 'theological terror', to use James Baldwin's expression" with Cope's rendering of Leroux):

I try to see humanity outside this restrictive context; I try to keep my novels free of politics in a narrow as well as a broad sense; even, if possible, free of literary politics [...] The characters in my books are maybe the horsemen on the apocalypse on the merry-go-round gyrating with anonymous deathmasks through my thoughts. So far as theme goes, I only ask to be left alone. I know it sounds blatant and provocative, but as a writer I am not interested in the weal and woe of the individual or of a particular group. I have a collective fear for human life with the consequence that all the characters in my books have become two-dimensional. So in terms of theme I am confined to my own special vision [...] Most novelists have only one book and one theme. My theme is fear and the exorcism of fear, and fear in its abstract manifestation is the most dire that there is. (The Adversary Within 117) 
Cope, in an essay revealingly entitled "Where the Sestigers Came Unstuck", written for Jim Polley's edited volume, Die Sestigers (1973), ascribes the "failure to resolve (exorcise)" the "fear or persecutory anxiety" he sees in this passage to "repressed guilt" resulting in the work taking "the form of a withdrawal into fantasy, a personal world from which he can send out his volleys of irony, rebellion, terror and mockery". It is also worth mentioning in this connection Cope's nostalgia (expressed at the Sestiger Symposium) for the "whole artist" of the Renaissance: "When I emphasize the shortcomings in theoretical work among our writers I guess I am calling for a kind of Renaissance ideal of the universal man" (Cope, "Sestigers" 151). This attitude is diametrically opposed to Leroux's vision of the individual in Sewe dae's epigraph, an individual "wat stuksgewys met ons nuwe insig verdwyn" ("that is systematically disappearing in the face of our new insight"; (Sewe dae 8). A. J. Coetzee provides a gloss in his entry on Afrikaans literature in Albert Gerard's key 1986 collection of literary-historiographical essays, European-language writing in sub-Saharan Africa (Vol $1)$ :

One of Leroux's fundamental theses is that modern man has lost his myths: this is why his characters are always reminded-often by a meturgeman or "guide of dreams" - of the importance of recognising these myths. In [...] Sewe dae by die Silbersteins [...] he makes use of Jung's concept of the individuation process to depict man's initiation into society (and, ironically, his loss of individuality). By implication, this stands for the South African's initiation into his country. (229)

Leroux's full statement concerning his own textual politics is as follows (italics indicate sentences cut by Cope):

My tema word nie beperk in terme van politiek-sosiale probleme nie. Ek probeer die mens sien buite hierdie bepalende verband; in 'n sekere sin probeer ek die roman vry maak van die politiek - politiek in'n eng sowel as in'n breë sin; selfs, indien moontlik, ook vry van die politiek van die letterkunde. Die politieke neiging is altyd links (op watter gebied ook al), met die remskoen van konserwatiewe reaksie sodat die mallemeule nie te vinnig draai nie. Ek probeer hierdie mallemeule op my eie manier hanteer. Die karakters in my boeke is miskien die apokaliptiese ruiters op die mallemeule wat met anonieme doodsgesigte rondomtalie deur my gedagtes jaag. Al wat ek vra, is om in terme van tema met rus gelaat te word. Ek weet dit klink blatant en uitdagend, maar ek as skrywer is nie geinteresseerd in die wel en wee van die enkeling, of die besondere groep nie. (Leroux, "Tegnieke" 133) ${ }^{8}$

Rendering "probeer ek die roman vry maak van die politiek" as "I try to keep my novels free of politics" instead of "I am trying to liberate the novel from politics" defuses the political charge of Leroux's speech, turning his vindication of the writer's creative sovereignty into a noli me tangere detachment. By entirely omitting the sentences from 
"Die politieke neiging [...] hanteer" ("Political inclination [...] in its own way"), Cope violates Leroux's image of politics as a merry-go-round propelled to the left but restrained by conservative reaction-a carousel that he wishes to handle in his own way; the image of the riders of apocalypse is uncoupled from the precedent, political image, fostering the perception of Leroux as an ivory-tower escapist rather than a writer committed to exorcising his collective fear for humanity in the only way he can, both in terms of subject matter and technique (the two-dimensionality of his characters refers obliquely to the emblematic structure of his novels). Crucially, Cope omits Leroux's final sentence: "Ek kan dit nie bekostig om anders te skryf nie." ("I cannot afford to write in any other way"; “Tegnieke” 133).

Further examination of Leroux's practice as writer makes it abundantly clear that Leroux was simply incapable of writing the kind of committed, overtly anti-apartheid literature that Chapman, and by all indications Gordimer, too (see below), seemed to want him to do as a South African writer. Realism in fiction held no interest for Leroux. Instead of traditional character formation and a microscopically detailed image of society and nature, he preferred to represent human beings with all their emotions in a chaotic process of thinking and feeling. Often he made his characters into caricatures used only to express a play of ideas: through their grotesque or absurd appearance and actions, the demonic aspect of life was exorcised; the task of interpretation was left to the reader. His characters were like actors on a stage, his dialogue not intended to be true to life. He endeavoured to convey his perceptions and beliefs intuitively rather than rationally: had he wished to convey a straightforward message, he would have written essays or articles.

What he did endeavour to convey was the myth of the twentieth century: in a world devoid of gods, in which opinion was biased against the irrational, people suddenly and abruptly had been severed from their primeval roots and were now in the grip of a sort of demonic power existing in the collective unconscious, from which new myths and symbols were being created.

Citing a letter in which his novels were likened to Rorschach tests where readers could read as they pleased, Leroux said that he liked to leave the reader a certain amount of leeway and expressly did not wish to convey a particular philosophy (Kannemeyer, Leroux 300-3).

Cornwell's claim that the label "'South African' has for long not only designated a national identity but also implicitly privileged writing which is in some important sense about South Africa, about 'the South African experience'" (Cornwell 7), is amply demonstrated by Chapman's evaluation of "Sestiger" writing: "Hailed as prophets, Leroux and Smit are also apes of God. Individual compassions are sublimated to the metaphysical Idea; black people, if they appear at all, are emblems of chaos and, as with earlier Afrikaans writers, the question of the Afrikaner's relation to any wider South African community is never posed" (Chapman 249). 
The statement about the fictional treatment of black people echoes that of an English reviewer who said that while Leroux's technique was outstanding among African novelists at the time, his subject matter left much to be desired because "there is never a nigger in sight" (Leroux, "Tegnieke" 133). To this, two objections may be raised. First, against the accusation that black people were no more than tokens of chaos, there is Ampie Coetzee's statement in Albert Gerard's European-language writing in sub-Saharan Africa: "The only indestructible symbol in the novel is the Coloured man Gert Garries whose personality fuses African and European elements so that he may appear as a prophetic type of future South African identity." (228-9)

Second, it may be inferred from Chapman's description of black people in Leroux as mere "emblems of chaos" that the imputation of chaos is necessarily pejorative. In this respect Chapman is shows a similar incomprehension of chaos as understood by Leroux as did the censorship apparatus of the State. As Leroux describes, the State and its legislators do not understand the deeper nature of chaos: they prescribe the rules for order, treat chaos symptomatically ("smeer die simptome van chaos toe"; "sweep the symptoms of chaos under the carpet"), and allow chaos to develop beneath the surface until it eventually erupts. The State does not acknowledge the value of writers, says Leroux: chaos has already erupted within them; their internal discipline allows them to give significant form to the nature of chaos in their creative work- a form that can be named and consequently exorcised ("Vervreemding tussen leser en skrywer" 7576).

Leroux then expands the concept of Jungian individuation to "die hele avontuur van die Derde Wêreld [veral Afrika]" ("the whole adventure of the Third World [especially Africa]"), describing a scene of world-wide transformation in which "Swart Afrika is die agtergrond waarteen [dit] hom afspeel" (Black Africa is the background against which it all plays out") ("Vervreemding" 77). The writer must eschew "die blote weergawe van oppervlakkige gegewe en die simptome van geweld en ongeregtheid [...] Moeder Afrika sal haar swartheid moet verwerk en ' $n$ betekenis aan haar argetipes gee. [...] Militante skrywers sal ook besef dat vurige sosio-politieke protes op die gebied van die letterkunde slegs 'n bepaalde en tydelike doel dien." (Leroux, "Vervreemding" 78)

It is necessary to find "' $\mathrm{n}$ lewende mite vir Afrika" ("a living myth for Africa") but given that true myth is "universeel, hibried, en dus allesinsluitend" ("universal, hybrid, and all-inclusive"), the urgency of this task is not limited to Africa but is applicable to the whole world: "Ons sal moet bewys dat 'never the twain shall meet' vals is" ("we will have to prove that 'never the twain shall meet' is false") (78). Leroux, then, was a novelist looking for deeper connections between Africa and the world; like J. M. Coetzee, one might reasonably argue, he felt uncomfortable with the implicit provincialism of a thoroughgoing South African exceptionalism, a condition that was later to be comprehensively quashed by political economist Mahmood Mamdani, 
who in his book Citizen and Subject (1996) insisted that the widespread South African self-image of specialness was illusory, and that the country was an integral part of a much larger African history, "with specific differences" (27).

The success of Leroux's mythopoeic endeavour to bridge the local and the universal is open to debate, but Chapman's imputation of apolitical aloofness clearly omits to consider, carefully and in full context, Leroux's published views on the relation between politics and writing.

Skeptical about the "Sestigers" from a political standpoint, Chapman is equally unimpressed by their technical achievements: "In looking back at the Sestigers, Jack Cope concluded that there was no coherent theory to the practice. With an overemphasis of technique that was usually conspicuous in its derivativeness and little engagement with the issues of race and politics, a sense of South African reality did not arise from the experience of the writing." (149)

Chapman's implicit prescription of a "sense of South African reality" is similar in kind to Nadine Gordimer's out-of-hand rejection of Leroux's work and scholar Vivienne Sheer's somewhat sheer dismissal of him, in the Journal of Southern African Studies in 1982, as catering to the inbuilt fears of the Afrikaner establishment ("Etienne Leroux's Sewe Dae"). Even though in 1976 Gordimer considered Leroux the "outstanding prose writer" among the "Sestigers" "and indeed the most sweeping imaginative power in South African literature as a whole", she opined: "If a writer is a part of the creative consciousness of the society in which he lives, is it not a form of betrayal [...] to choose to turn away from the messy confrontation of man with man, and address himself to God? In fact, reading [the trilogy], you sometimes have the feeling that Etienne Leroux is God [...] amusing himself by recording all those absurd and dirtily flamboyant little battles and copulations way down on earth" (Berner 136). For Berner, Gordimer clearly does not value Leroux's fantastic mode and assumes that "pending the coming of the peaceable kingdom, literary realism is the only appropriate approach to South African material" (136). However, it is precisely Leroux's technical accomplishments that repay attention today.

Although Leroux's role as innovator within Afrikaans literature is still acknowledged, within South African literary historiography as a whole, the credit for renewal goes to a much more internationally famous South African writer: J. M. Coetzee. As Green states, it is "a truism of southern African literary history that no sustained modernist tradition was produced here in chronological relation with the metropolitan modernist period", with Plomer's Turbott Wolfe "the nearest thing to a precursor for the narrative modernist forms Coetzee is usually credited with introducing to South African fiction" (787-8; italics added).

Yet Leroux and Coetzee share a formal resemblance with regard to at least one aspect of these "narrative modernist forms". In a discussion on the influence of the French nouveau roman on The Heart of the Country (1977), the novel which "confirmed 
the writer's considerable ability and demonstrated the importance of Afrikaner readiness to experiment for the development of the South African English novel" (Wade 249), Coetzee acknowledged that similarities existed. However:

behind both there is, I think, a more fundamental influence: film and/or photography. There was a moment in the course of high modernism when first poets, then novelists, realized how rapidly narration could be carried out: films that used montage effectively were connecting short narrative sequences into longer narratives much more swiftly and deftly than the nineteenth-century novelist had thought possible, and they were educating their younger audience too into following rapid transitions, an audience that then carried this skill back into the reading of printed texts. (Coetzee, Doubling the Point 59)

The influence of film in Leroux was noted by Graham Greene, in 1968:

Mr. Leroux writes his books in static scenes; between them he allows his camera to track rapidly and wildly around his location. The influence of the cinema is clearnot the conventional cinema but the cinema of Robbe-Grillet or Godard. Dr. Johns serves the narrative much as the coloured subtitles of Godard serve his films, not explanatory, but ironic, decorative, absurd (Malan, Die Oog van die Son 118).

In addition to film, Leroux's technique demonstrably bears other traces of distinctly Modernist provenance: the meta-irony of Duchamp, for example, is manifest in Leroux's playful self-reflexiveness and widespread use of détournement, while the use of the conjunction of opposites as a structuring device draws equally from the syzygies of both ur-Modernist Alfred Jarry and Carl Jung.

In view of these considerations, it is high time to consider Leroux's contribution to South African literature as a whole, rather than the subset represented by the Afrikaans canon as translated into English. As a preliminary to this endeavour, substantial translation work would be required, from the stand-alone classic Magersfontein, $O$ Magersfontein! to the nine-novel cycle in its entirety. Fortunately, the practice of translation itself provides an invaluable hermeneutic tool. The first step in this process has been completed: a new translation of Sewe dae has been completed by the first author, supervised by the second author, for an MA degree at Stellenbosch University (Penfold). The translation differs in crucial respects from the existing one by Eglington in that it relies on a keen appreciation of Leroux's modernism and, in particular, on an appreciation of Leroux's intertextual play with the sign of Ubu in relation to urModernist Alfred Jarry's concept of pataphysics, among other features. 


\section{Notes}

1. All translations, unless otherwise specified, are ours; short translations are presented in the text while longer ones are presented in the "Notes".

2. Clearly Leroux's celebrated "musical" form, with its circulating images, refrains, and motifs draw from Wagner's Der Ring des Nibelungen (Van Coller 10), was not sufficiently visible in translation.

3. According to personal correspondence between Stephen Gray and the first author, Gray and a student, Louis van Rooyen, in 1974 "undertook to translate $N a^{\prime} v a^{\prime}$. The translation was duly completed and handed over to Human \& Rousseau. Gray adds: "To the best of my knowledge, it is still in the archives of Human \& Rousseau. I've never heard of its being lost by any agent, so I think Kannemeyer is wrong." Gray also reports that he deposited "attempted translations by SG of the opening pages of his [Leroux's] 18-44 and $\mathrm{Na}^{\prime} \mathrm{va}$ (March, 1974)", as well as correspondence with Leroux (11 letters and two telegrams, including a copy of an earlier letter from Leroux to Eglington), at the Harry Ransom Centre (HRC) at the University of Texas, Austin.

4. "In the image held by Europeans of South African literature, the European preoccupation with racial conflict takes centre-stage. Any South African novel that ignores Apartheid is relegated to the rubbish bin or is regarded at most as a historically relevant document. Since the 1970s, information about the fortunes of South Africa have been communicated in such a strongly detailed manner in the European media that the expectations of the European reading public with regard to fictional prose coming out of South Africa have changed substantially." (Italics added)

5. "I prefer the indigenous peoples' own myths drawn from the same geographical regions. Or Nadine Gordimer's white foment [...] Does the book actually present an image of the disintegration of South Africa? The disappearance of European civilization? Yes, probably. But it does this dressed up in such complicated veils that contact with the human element remains absent. In such a case it becomes difficult to retain the reader's interest."

6. This uncritical acceptance of Brink's "admission" underscores the extent to which he has been able to control his literary image.

7. Note how Chapman adapts Cope's previously cited "blood and soil" to his own discourse.

8. "My theme is not delimited in terms of sociopolitical problems. I try to see humanity outside this restrictive context; I try to keep my novels free of politics in a narrow as well as a broad sense; even, if possible, free of literary politics. Political inclination always tends to the left (regardless of subject matter), held back by the restraining force of conservative reaction so that the merry-go-round doesn't turn too fast. I try to deal with this carousel in my own way. The characters in my books are maybe the horsemen of the apocalypse on the merry-go-round gyrating with anonymous deathmasks through my thoughts. So far as theme goes, I only ask to be left alone. I know it sounds blatant and provocative, but as a writer I am not interested in the weal and woe of the individual or of a particular group."

9. "[T]he mere rendition of superficial phenomena and the symptoms of violence and injustice ... Mother Africa will have to work through her blackness and lend her archetypes their own significance. [...] Militant writers will also realize that fiery sociopolitical protest in the area of literature will serve only short-term and particular purposes") (Leroux, "Vervreemding" 78).

\section{Works Cited}

Attwell, David, and Derek Attridge, eds. The Cambridge History of South African Literature. Cambridge: CUP, 2012.

Bell, Daniel. The Coming of Post-Industrial Society. New York: Basic Books, 1973.

Berner, Robert. "Etienne Leroux: a Jungian Introduction." Vanwëe die Onbewuste. Ed. Charles Malan and H. P. Van Coller. Pretoria: HAUM, 1987. 14-22.

Brink, André P. "Voorwoord." Magersfontein, O Magersfontein! Etienne Leroux. 1976. First classic edition. Cape Town: Human \& Rousseau, 2003. n.p.

Botha, Elize. "Etienne Leroux (1922-1989)." Perspektief en profiel: 'n Afrikaanse literatuurgeskiedenis. Ed. H. P. van Coller. Pretoria: J.L van Schaik Uitgewers, 1998. 586-603.

Bourdieu, Pierre. Distinction: A Social Critique of the Judgement of Taste. Trans. Richard Nice. Cambridge: Harvard UP, 1984.

Chapman, Michael. South African Literatures. Pietermaritzburg: U of Natal P, 2003.

Coetzee, A. J. (Ampie). "Afrikaans." European-Language Writing in Sub-Saharan Africa: 1. Ed. Albert S. Gérard. Amsterdam/Philadelphia: John Benjamins, 1986. 217-30. 
Coetzee, J. M. Doubling the Point: Essays and Interviews. Ed. David Attwell. Cambridge: Harvard UP, 1992. . and André Brink, eds. A Land Apart: A South African Reader. London: Faber and Faber Limited, 1986.

Collins, Randall. The Credential Society: A Historical Sociology of Education and Stratification. New York: Academic Press, 1979.

Cope, Jack. The Adversary Within: Dissident Writers in Afrikaans. Cape Town: David Philip, 1982.

. "Where the Sestigers Came Unstuck." Die Sestigers. Verslag van die simposium oor die Sestigers gehou deur die Departement Buitemuurse Studies van die Universiteit van Kaapstad, 12-16 Februarie 1973. Ed. Jim Polley. Cape Town and Pretoria: Human \& Rousseau, 1973. 149-51.

Cornwell, Gareth. "Long Walk To Ordinariness." The Columbia Guide to South African Literature in English Since 1945. Ed. Gareth Cornwell, Dirk Klopper and Craig Mackenzie. New York: Columbia UP, 2010. 1-42.

English, James F. The Economy of Prestige: Prizes, Awards, and the Circulation of Cultural Value. Cambridge, MA: Harvard UP, 2009.

Ester, Hans. "Etienne Leroux en de Literatuur van de Jaren Tachtig." Vanwëe die Onbewuste. Ed. Charles Malan and H. P. van Coller. Pretoria: HAUM, 1987. 102-15.

Even-Zohar, Itamar. "Polysystem Theory." Poetics Today 1.1/2 (1979): 287-310.

France, Peter, ed. The Oxford Guide to Literature in English Translation. Oxford: OUP, 2000.

Gray, Stephen, ed. Writers' Territory. Cape Town: Longman, 1973.

Green, Michael. "The Experimental Line in Fiction." The Cambridge History of South African Literature. Eds. David Attwell and Derek Attridge. Cambridge: CUP, 2012. 779-99.

Kannemeyer, J. C. A History of Afrikaans Literature. Pietermaritzburg: Shuter \& Shooter, 1993.

- J. M. Coetzee: A Life in Writing. Trans. Michiel Heyns. Johannesburg and Cape Town: Jonathan Ball, 2012.

- Leroux: 'n Lewe. Pretoria: Protea Boekhuis, 2008.

Op Weg na Welgevonden. Pretoria: Academica, 1970.

Lefevere, André. Translation, Rewriting, and the Manipulation of Literary Fame. London/New York: Routledge, 1992.

Leroux, Etienne. Een vir Azazel. Cape Town: Human \& Rousseau, 1964.

. Die derde oog. Cape Town: Human \& Rousseau, 1966.

. Die eerste lewe van Colet. Cape Town: HAUM, 1968.

Hilaria. Cape Town: Culemborg, [1957].

. Isis, Isis, Isis. 'n Storie van dertien vrouens en 'n resibeskrywing na binne. Cape Town: Human \& Rousseau, 1969.

—. Magersfontein, O Magersfontein! Cape Town: Human \& Rousseau, 1976.

. Magersfontein, O Magersfontein! Trans. Ninon Roets. Cape Town: Hutchinson, 1983.

. Magersfontein, O Magersfontein! Trans. Ingrid Glorie. Amsterdam: Uitgeverij Podium, 1999.

. Die mugu. Cape Town: HAUM, 1962.

. Na'va. Cape Town: Human \& Rousseau, 1972.

One for the Devil. Trans. Charles Eglington. Boston: Houghton Mifflin, 1968.

One for the Devil. Trans. Charles Eglington. London, W. H. Allen, 1969.

Seven Days at the Silbersteins. Trans. Charles Eglington. Johannesburg: Central News Agency, 1964.

Seven Days at the Silbersteins. Trans. Charles Eglington. London : W. H. Allen, 1968.

Sewe Dae by die Silbersteins. Cape Town: Human \& Rousseau, 1962.

"Tegnieke, Temas en Toekomsplanne." Die Sestigers. Verslag van die simposium oor die Sestigers gehou deur die Departement Buitemuurse Studies van die Universiteit van Kaapstad, 12-16 Februarie 1973.

Ed. Jim Polley. Cape Town and Pretoria: Human \& Rousseau, 1973. 126-39.

. The Third Eye. Trans. Amy Starke. Boston: Houghton Mifflin, c1969.

. The Third Eye. Trans. Amy Starke. London, W. H. Allen, 1969.

. To a Dubious Salvation: A Trilogy of Fantastical Novels. Harmondsworth: Penguin, 1972.

Tussengebied. Johannesburg; Cape Town: Perskor, 1980.

"Vervreemding tussen leser en skrywer." Skrywer en Gemeenskap. Ed. Charles Malan and Bartho Smit. Pretoria: HAUM-Literêr, 1987. 
18-44. Cape Town: Human \& Rousseau, 1967.

18-44. Trans. Cassandra Perry. Boston: Houghton Mifflin, 1972.

Malan, Charles. "Die krisis van die subjek in die soektog na betekenis." Vanwëe die Onbewuste. Ed. Charles Malan and Hendrik Petrus van Coller. Pretoria: HAUM, 1987. 56-71.

Malan, Charles, ed. Die oog van die son: Beskouings oor boeke en werk van Etienne Leroux. Pretoria, Cape Town, Johannesburg: Academica, 1982.

Malan, Charles, and H. P. van Coller, eds. Vanwëe die onbewuste. Pretoria: HAUM, 1987.

Mamdani, Mahmood. Citizen and Subject: Contemporary Africa and the Legacy of Late Colonialism. Princeton: Princeton UP, 1996.

Olivier, Gerrit. "The Dertigers and the plaasroman". The Cambridge History of South African Literature. Eds. David Attwell and Derek Attridge. Cambridge: CUP, 2012.

Ousby, Ian. The Cambridge Guide to Literature in English. Cambridge: CUP, 1993.

Penfold, Greg. "Welgevonden Revisited: A New Translation of Sewe Dae by die Silbersteins, and its Literary-Critical Rationale". M.A. diss., Stellenbosch University, 2013.

Rogers, Jane, ed. Good Fiction Guide. Oxford: OUP, 2001.

Sheer, Vivienne. "Etienne Leroux's Sewe Dae by die Silbersteins: A Reexamination in the Light of its Historical Context." Journal of Southern African Studies 8.2 (2008): 173-86.

Van Coller, H. P. Tussenkoms. Pretoria: HAUM, 1990.

Wade, Michael. "English." European-Language Writing in Sub-Saharan Africa: 1. Ed. Albert S. Gérard. Amsterdam/Philadelphia: John Benjamins, 1986.

Willemse, Hein. "Afrikaans Literature, 1948-1976." The Cambridge History of South African Literature. Eds. David Attwell and Derek Attridge. Cambridge: CUP, 2012. 429-51. 